\title{
FORMING AND DISCLOSURE OF INFORMATION ON RISKS RELATED TO FOREIGN BUSINESS
}

\author{
Anastasiya O. Matveeva ${ }^{1}$ \\ Lidiya I. Kulikova ${ }^{2}$
}

\begin{abstract}
Currently it is difficult to overestimate importance of work of the enterprises of fuel and energy branch, in particular the oil-extracting companies, the majority of which foreign divisions have. Conducting foreign activity involves numerous external risks, many of which are capable to influence a financial position and financial results of the company negatively. Practice shows that most the enterprises very formally belong to disclosure of information on the risks interfaced to foreign activity. The PEST analysis which is carried out by us allowed revealing risks to which the PJSC Tatneft Company having

considered. On the basis of the analyzed disclosure merits and demerits in the reporting of information on the risks interfaced to conducting foreign activity the uniform technique of disclosure of similar information was developed. In our opinion, the recommended format of disclosure of relevant information will simplify work of the accountant by drawing up financial statements, and to users of such reporting will allow to estimate consequences of foreign activity, to create idea of a financial position of the organization and will provide adoption of rational economic decisions.
\end{abstract} representation in Libya is subject. In this article practical implementation of requirements of IFRS regarding disclosure in the reporting of information on risks by the PJSC Tatneft Company having division abroad is also

Keywords: foreign activity, risk, IFRS, estimated obligations.

\section{Introduction}

\footnotetext{
1Kazan Federal University, Institute of Management, Economics and Finance, e-mail: matveevaao@mail.ru, Tel.+79178845556.

${ }^{2}$ Kazan Federal University, Institute of Management, Economics and Finance
} 
The domestic companies functioning today in the conditions of globalization and internationalization understand that their financial and economic activity, as well as the economy of our country, came [12] to absolutely new level of cooperation and competition.

It is known that on oil and gas production, the Russian Federation takes the second place in the world, and $37,4 \%$ of the budget of our country make the oil and gas income. These figures and the facts emphasize importance of work of the enterprises of fuel and energy branch, in particular the oil-extracting companies, the majority of which foreign divisions have now.

Conducting foreign activity is accompanied by numerous external risks, many of which are capable to influence a financial position and financial results of the company [11] negatively. The majority of the risks interfaced to foreign activity have unpredictable character and to avoid consequences of their emergence it is represented impossible. In that case in advantageous situation there are enterprises capable to quickly reveal similar risks and to quickly eliminate their consequences. It means that
66

competitive advantage of conducting activity abroad depends on successful risk management, connected with such activity.

The concept of foreign activity reveals in IFRS (IAS) 21 "Influence of changes of exchange rates of currencies" [3] in value of the company which is the affiliated, associated or joint venture, or division of the reporting enterprise which implementation of activity happens in the country or in the currency different from the country or currency of the reporting enterprise.

Today the lion's share of the domestic companies of an oil and gas complex conducts activity not only in the territory of Russia, but also abroad. So, PJSC Lukoil has oil refineries in Ukraine, in Romania and Bulgaria; PJSC Gazprom will enter foreign activity in Belarus, Namibia, Kyrgyzstan; PJSC Tatneft - in Ukraine, in Belarus, Libya, Syria and Turkmenistan. Therefore, success and prosperity of such companies is directly proportional to their ability to work in rapidly changing conditions of the world environment. We will call such conditions of uncertainty and unpredictability risk.

\section{Materials and Methods}


Formation and disclosure by the accountant of information on the financial risks connected with foreign activity was analyzed on the basis of accounting (financial) reports of the export company - PJSC Tatneft. This reporting reflects a financial position and financial results of activity of the company for 2016.

On the basis of the consolidated financial statements (further - KFO) the PJSC Tatneft company kept according to requirements of IFRS analyzed practical aspect of formation and disclosure of information on risks of implementation of foreign activity.

The information which is contained in standard and legal sources and concerning the risks interfaced to conducting activity abroad was analyzed (IFRS, IAS, the Information letter of the Ministry of Finance of the Russian Federation, etc.).

PEST analysis of risks of the PJSC Tatneft organization in a section of the division conducting activity in Libya was carried out.

\section{Results and Discussion}

IFRS standard (IFRS) 7

"Financial instruments: disclosure of
67

information" [2] is defined the operating classification of financial risks which includes credit risk, risk of liquidity and market risk. The last is subdivided on percentage, currency and other price risks. This classification of risks is presented also in the Information letter of the Ministry of Finance of the Russian Federation No. PZ-9/2012 [5].

We believe that the given classification of risks is applicable for disclosure of information on foreign activity of the companies. So, activity of foreign division, say, by PJSC Lukoil in Romania is really accompanied by credit risk (risk of non-performance or untimely performance by the borrower of the company of the financial obligations), risk of liquidity (when there is a probability that losses in connection with impossibility of the company to fulfill the obligations in time will be suffered) and market risk (risk of possible depreciation of assets as a result of the change in price for them).

At the same time, this classification is not information, universal and rather full for disclosure, in accounting reports about foreign activity of the companies. Let's consider risks to which the PJSC Tatneft company having representation abroad (in Libya), on the 
basis of PEST analysis (tab. 1.1) is

subject.

Table 1 - PEST analysis of risks of foreign activity of PJSC Tatneft in Libya

\begin{tabular}{|c|c|}
\hline & isks \\
\hline $\begin{array}{l}\text { Risk of military operations and civil disorders } \\
\text { (civil war in Libya, 2011); } \\
\text { Risk of a rupture of the contract because of } \\
\text { changes in the legislation of Libya } \\
\text { (unprofitable conditions, trade barriers, } \\
\text { increase in duties, taxes, etc.); } \\
\text { Risk of a transfer (difficulty of converting of } \\
\text { Libyan dinar in currency of submission of the } \\
\text { reporting because of actions of the government } \\
\text { of Libya). }\end{array}$ & $\begin{array}{l}\text { Risk of change of level of education of the } \\
\text { population of Libya (qualification and } \\
\text { professionalism which have shots); } \\
\text { Feature of mentality and important cultural } \\
\text { values; } \\
\text { Changes in social groups of the population of } \\
\text { Libya; } \\
\text { Risk of change of tastes and preferences of the } \\
\text { population of Libya; } \\
\text { Risk of change of the settled values and } \\
\text { prejudices. }\end{array}$ \\
\hline & \\
\hline $\begin{array}{l}\text { Risk of change in the exchange rate of } \\
\text { currencies (currency risk); } \\
\text { Change of unemployment rate; } \\
\text { Change of the rate of inflation; } \\
\text { Risk of change of the located income per } \\
\text { capita Libya; } \\
\text { Number of tendencies of a banking system of } \\
\text { Libya. }\end{array}$ & $\begin{array}{l}\text { Risk of possible changes in the main technologies } \\
\text { used at investigation, drilling and oil production } \\
\text { in the territory of Libya; } \\
\text { Innovations in information technologies, a certain } \\
\text { business model, ways of the organization and } \\
\text { business; } \\
\text { Risk of influence of mobile technologies and the } \\
\text { Internet on development of cooperation at world } \\
\text { level. }\end{array}$ \\
\hline
\end{tabular}


As a rule, the risk of conducting foreign activity has negative financial consequences. For example, suppose, that the resident of the Russian Federation, the oil-extracting company PJSC Rusneftedob, conducts foreign activity in Kuwait. As a result of unforeseen circumstances, say, of the fire which happened because of arson of oil wells, activities for extraction of "black gold" stopped. The independent organization assessed damage caused by natural disaster at a rate of 37850 Kuwaiti dinar: oil reserves were destroyed, boring wells demand considerable repair and office buildings are not subject to restoration. Thus, PJSC Rusneftedob will suffer considerable financial losses, trying to stabilize the reeled financial stability of the company.

As similar situations exert direct impact on results of financial activity of the economic subject (the company incurs losses, there is an outflow of its money, an expenditure of financial, labor, material and production resources), so this information has to be reflected in accounting reports of the enterprise. It is urgent also because according to requirements of IAS 1 "Submission of financial statements" [1], information on risks reflected in the reporting has to be relevant, convenient and demanded by the users interested in information on foreign activity of the organization.

According to requirements to disclosure of information on risks in the reporting the company is obliged to provide to users information on all types of risks in a part:

- susceptibility of the company to risks and reasons of their emergence;

- concentration of risk (the company has to describe a concrete general characteristic which distinguishes each concentration on contractors, regions, currency of calculations and payments);

- the risk management mechanism (disclosure is more whole, politicians, the applied procedures in the field of the risk management and methods used for risk assessment);

- changes on all abovementioned points current reporting year in comparison with previous.

Now in activity of the largest companies questions of management of political risks as mechanism of maintenance of stability of functioning and development of economic entity are 
very urgent. However, despite considerable importance of formation of information, for the purpose of improvement of quality of financial statements, the analysis of accounting reports of one of the largest export companies of Russia which is carried out by us showed that it very formally treats disclosure of information on risks.

Let's consider how information on the risks connected with a political situation in the reporting of PJSC Tatneft is opened. In the Note 27 "Conditional and contractual obligations" the company describes the susceptibility to political risk in Libya, specifying the reason (The civil war in Libya) and consequences (the enterprise was forced to suspend completely the activity in Libya and to evacuate all the employees) its emergence. Data on the sum of the assets connected with operations in Libya (5 752 million rubles) as a part of which there are capitalized costs of investigation (5 532 million rubles), inventory holdings (210 million rubles) and money (10 million rubles) are here too provided.

However in the analysis of the Note 30 "Management of financial risks" it was revealed that PJSC Tatneft has no strategy of management of political risks directed to minimization of potentially possible negative effect on a financial position of group. In other words, the situation in Libya is described only in the Note of the 27th annual reporting of PJSC Tatneft.

Lack of such order of disclosure of information, in our opinion, is lack of data as about the size of the risks connected with a political situation in Libya and about the size of consequences of their influence on activity of the company in terms of money. There is also no information on risks of foreign activity in Ukraine, Belarus, Syria and Turkmenistan.

\section{Conclusions}

On the basis of the carried-out PEST analysis it is possible to draw a conclusion that the existing classification of financial risks is not full and, in our opinion, can be applicable to foreign activity at its addition with a new qualification sign - the risks connected with a political situation in the world or political risks. Risks which possibility of approach is probable in connection with political actions of the government of that country in which the reporting enterprise has the division will belong to 
this category. As recommendations we would like to offer such way of submission of information on risks of conducting activity abroad which, in our opinion, draws the fullest picture of risks, improving transparency and reliability (qualitative characteristics) of financial statements (fig. 1). He will allow users of financial statements to have more detailed and objective idea of a financial position of the company with the smallest expenses of time for search of necessary relevant information.

This way of submission of information is based on assessment of risks of foreign activity according to PEST analysis where risks are ranged on extent of their influence on economic security of business. It is necessary for those risks which have the high level of threat for a continuity of activity of the organization: - $\quad$ to open consequences of their influence (in particular, their influence on indicators (articles) of financial statements in terms of money);

- to specify the tools used for assessment of the arising risks;

- to develop methods of their minimization and the subsequent control.

\begin{tabular}{|c|c|c|c|}
\hline \multirow{2}{*}{$\begin{array}{l}\text { Article of financial statements } \\
\text { subject to risk of foreign activity }\end{array}$} & \multicolumn{3}{|c|}{ Political risk } \\
\hline & Libya & $\ldots$ & Country $n$ \\
\hline \multicolumn{4}{|l|}{ Long-term assets } \\
\hline Capital expenditure according to the section & 5532 & $\ldots$ & $\sum n$ \\
\hline Search NMA & 1321 & $\ldots$ & $\sum n$ \\
\hline & $\ldots$ & $\ldots$ & $\ldots$ \\
\hline Total long-term assets & 6853 & $\ldots$ & $\sum n$ \\
\hline \multicolumn{4}{|l|}{ Short-term assets } \\
\hline Money and their equivalent & 10 & $\ldots$ & $\sum n$ \\
\hline Inventory holdings & 210 & $\ldots$ & $\sum n$ \\
\hline & $\ldots$ & $\ldots$ & $\ldots$ \\
\hline Total short-term assets & 220 & $\ldots$ & $\sum n$ \\
\hline \multicolumn{4}{|l|}{ Share capital } \\
\hline & $\ldots$ & $\ldots$ & $\ldots$ \\
\hline Total akpitat joint-stock & $\ldots$ & $\ldots$ & $\sum n$ \\
\hline \multicolumn{4}{|l|}{ Lōng-term circumstances } \\
\hline $\begin{array}{l}\text { Estimated obligations for a conclusion of } \\
\text { operation of an asset }\end{array}$ & 3578 & $\ldots$ & $\sum n$ \\
\hline & $\ldots$ & $\ldots$ & $\ldots$ \\
\hline Toțal long-term obligations & 3578 & $\ldots$ & $\sum n$ \\
\hline \multicolumn{4}{|l|}{ Short-term obligations } \\
\hline Estimated obligations for payment & 5 & $\ldots$ & $\sum \pi$ \\
\hline$\cdots$ & $\ldots$ & $\ldots$ & $\ldots$ \\
\hline Total short-term obligations & 5 & $\ldots$ & $\sum n$ \\
\hline
\end{tabular}


Figure 1 - The data representation form offered by authors about the risks connected with foreign activity of PJSC Tatneft

This approach can be realized by means of the analysis of sensitivity which helps, changing initial risk components, to estimate their influence on final characteristics. The analysis of sensitivity in practice is carried out by means of application of special computer programs which part of tools methods of imitating modeling (Project Expert, "AltInvest"), or the Microsoft Excel programs are (the analysis "that-if"). Thus, application of modern methods of forecasting and disclosure of the received results in the reporting will lead to improvement of quality of the last that will raise its representative characteristics.

It is also necessary to think over methods of registration ensuring formation of information on the risks interfaced to a political situation. In our opinion, creation of estimated obligations for similar situations is expedient $[6,7]$.

First, consequences of this political situation in Libya gets under definition of the estimated obligation opened in IFRS (IAS) 37 which are understood as the obligation with an uncertain date of performance or the obligation of uncertain size [4,13]. Really, terms in which PJSC Tatneft plans to resume the activity in Libya remain unknown to this day.

Secondly, according to the last audit inspection of the reporting of PJSC Tatneft by the PricewaterhouseCoopers company (PwC) the used importance level in relation to each concrete enterprise made from 130 million rubles to the maximum level making 5400 million rubles. It turns out that the unaccounted sum of assets on operations in Libya for the sum of 5752 million rubles is essential.

In this regard, we consider that PJSC Tatneft needs to create the estimated obligation for a conclusion from operation of assets of investigation and assessment in the sum calculated for requirements of IFRS (IAS) 37 "Estimated obligations, conditional obligations and conditional assets". The article "The Estimated Obligation for a Conclusion from Operation of Assets of Investigation and Assessment" will be included in the report on a financial position of PJSC Tatneft in the section of 
long-term obligations. In the report on the cumulative income the sum of the created estimated obligation will be reflected under the article "Other expenses". Information on this estimated obligation needs to be opened in notes to financial statements of the company.

All this will allow PJSC Tatneft:

- to secure itself against possible losses which can be suffered in the future in connection with the developed political situation in Libya (in the sum of the created estimated obligation);

to provide registration and analytical formation of information on risks of foreign activity;

- $\quad$ to provide to users and investors information which is precisely reflecting a financial position of the company.

\section{Conclusion}

Thus, the classification of risks presented in IFRS (IFRS) 7 is applicable to risks of conducting activity abroad, but is not limited to credit, market risk and risk of liquidity, and can be added with risks political. Information on the risks of foreign activity connected with a political situation has to be opened in notes to accounting (financial) reports. Risks have to be ranged through the PEST analysis prism on extent of influence on financial and economic activity of the economic subject. Influence of the most essential risks has to be counted by means of the analysis of sensitivity and is reflected in quantitative (monetary) expression in a section of the countries where foreign activity of the company, and under articles of accounting reports is conducted.

Also creation of estimated obligations in those situations when the date of performance or size of such obligation cannot be precisely defined is recommended. Such event is the termination of trade operations of PJSC Tatneft in the territory of Libya because of the developed political situation in this country.

Only set of the above-stated actions is capable to improve quality, transparency and appeal of the provided accounting information from the point of view of the interested users that, in turn, will promote adoption of rational administrative decisions by the management. 


\section{ACKNOWLEDGEMENTS}

The work is performed according to the

Russian Government Program of

Competitive Growth of Kazan Federal

University.

\section{References}

International Financial Reporting

Standard (IAS) 1 "Submission of

financial statements".

International Financial Reporting Standard (IFRS) 7 "Financial instruments: disclosure of information".

International Financial Reporting Standard (IAS) 21 "Influence of changes of exchange rates of currencies".

International Financial Reporting Standard (IAS) $37 \quad$ "Estimated obligations, conditional obligations and conditional assets".

Information of the Ministry of Finance of the Russian Federation No. PZ-9/2012 "About disclosure of information on risks of economic activity of the organization in annual accounting reports".
Kulikova L. I. Formation of estimated reserves//Financial messenger. - 2011. No. 5. Page 70-79.

Kulikova L. I. Estimated obligations: recognition in the account and assessment / L.I. Kulikova//Accounting, 2011, No. 5, page 30-32.

Ukhteeva N. A. Features of application of IFRS 37 "Estimated obligations, conditional obligations and conditional assets"//International accounting. - 2008. - No. 10 (18). Page 25-31.

Castoldi, Stefano. IAS 37, Provisions, contingent liabilities and contingent assets//Luic. - 2015. - No. 3 (14). P.7281.

Craig Burnside. Currency crises and contingent liabilities//Journal of International Economics. - 2004. - No. 1. P. 25-52.

Karen M. Hennes. Disclosure of contingent legal liabilities//Journal of Accounting and Public Policy. - 2014. No. 1. P.32-50.

A.S. Koshkarova, A.K. Atabayeva. Definition and procedure of provisions, 
contingent liabilities and contingent

assets in the financial

statements//Science and world. - 2014. -

No. 3 (7). P.76-81.

L.I. Kulikova, G.I. Khamidullina, A.V.

Goshunova and P.A. Aletkin.

Methodological Aspects of Reserve

Funds Accounting, Based on the

Concept of Capital Maintenance in Joint

Stock Companies//The Social Sciences. -

2017. - No. 12. Page 208-214.

Tian, Ze. Research on the Prevention of

Information Risk in Business

Communication of Foreign Trade

Enterprises//Journal of Changsha

University. - 2013. - No. 4. - P.14-18.

Wang, Min. Research on Export Credit

Risk Management of Foreign Trade

Enterprises//Contemporary Logistics. -

2014. - No. 5. P.71-75 